\section{No jail for geneticist who posted bacteria to artist}

A researcher at the University of Pittsburgh, Pennsylvania, last week escaped a jail sentence but was fined US $\$ 500$ for sending bacterial samples to a performance artist in Buffalo, New York.

In 2004, geneticist Robert Ferrell supplied Steven Kurtz, an art professor at the State University of New York at Buffalo, with samples of Bacillus globigii, Serratia marcescens and a benign form of Escherichia coli. Kurtz used bacteria in experiments involving the audience to explore attitudes towards bioterror and genetic engineering in shows by his performance art troupe, the Critical Art Ensemble.

Kurtz's wife suffered a fatal heart attack in May of that year. Emergency workers who arrived at the artist's home became suspicious when they found the samples and laboratory equipment (see Nature 429, 690; 2004). Federal prosecutors later charged Ferrell and Kurtz with mail and wire fraud.

Last October, 64-year-old Ferrell pleaded guilty to one count of mailing an injurious article. He describes the prosecution as a "nuisance". Kurtz still faces prosecution and is fighting to have the case thrown out.

\section{Funds run dry for sea-fertilization project}

Ocean-fertilization company Planktos has indefinitely suspended its plans for large-scale dumping of iron powder in the ocean. The company claimed that such a project would have seeded phytoplankton blooms to sequester carbon from the atmosphere. Eventually, Planktos said, the phytoplankton would sink to the ocean floor, taking their carbon with them.

"A highly effective disinformation campaign waged by anti-offset crusaders" made raising the required funds difficult, the company based in Foster City, California, stated last week.

But critics say that more research is needed to understand the possible environmental effects of such large-scale iron releases, including hypoxia and the production of other greenhouse gases.

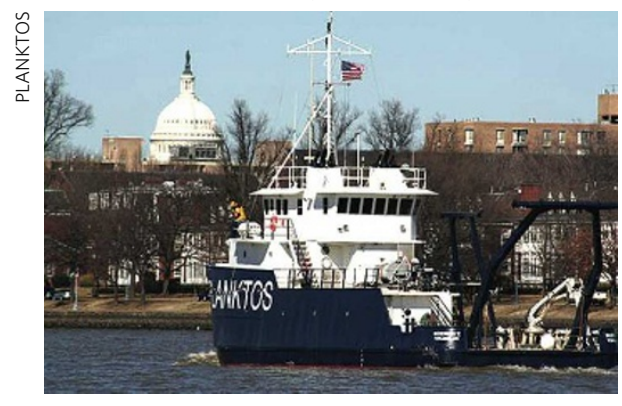

Planktos has halted its plans for iron fertilization.

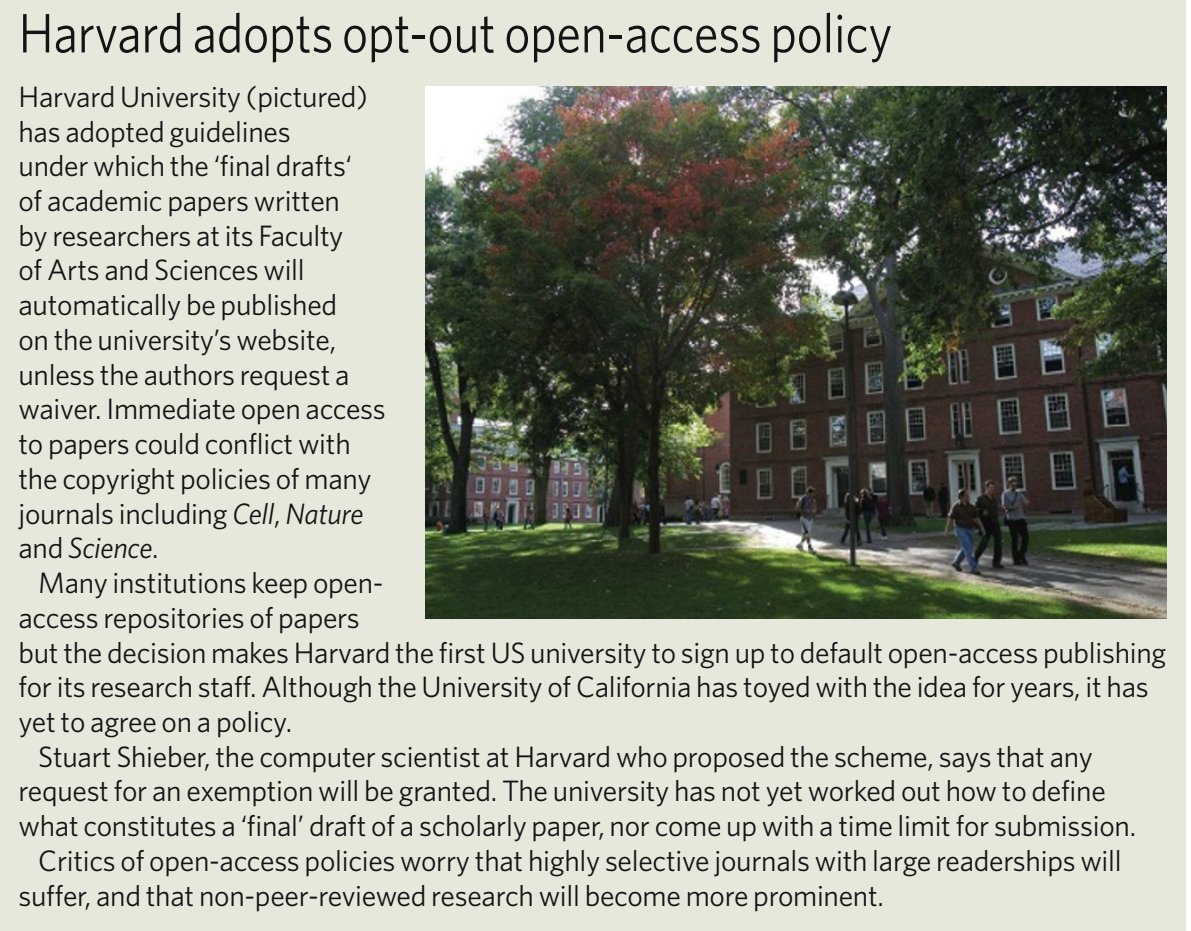

\section{Systems biologists hatch plan for virtual human}

Researchers in the fledgling field of systems biology have laid down the challenge of creating a molecule-based computational model of a person that could be of use to the pharmaceutical industry.

The 'virtual human' would simulate the interactions between the tens of thousands of human proteins and other cellular components, such as non-coding RNA. Researchers agreed to try to create such a model within the next 30 years at a threeday workshop in Tokyo earlier this month.

If the plan goes ahead, it would require the development of new technologies and collaborations between researchers from different countries and disciplines, says Hiroaki Kitano, director of the Systems Biology Institute in Tokyo. Kitano hopes that the ambitious goal will help win support from Japanese and UK funding bodies for research into systems biology.

\section{India has a key satellite antenna stolen for scrap}

A crucial Global Positioning System (GPS) antenna in Bangalore has been stolen - apparently for its scrap value - knocking India out of an international network of 'core' stations that provides data to geoscientists around the globe.

The station at the Indian Institute of Science was linked to the International Global Navigation Satellite Systems Service, based in Pasadena, California. The service provides scientific data such as for satellite navigation and earthquake-risk monitoring. Although India has 2 of the 336 active stations in the global network, the Bangalore station was the only one among the 40 core stations that supply data in real time.

The loss means that the "global Earthscience community will not have real-time GPS data from the Indian subcontinent", says Sridevi Jade a geoscientist at Bangalore's Centre for Mathematical Modelling and Computer Simulation, which maintains the station. She says that it will take a year to erect a new antenna in the same location and make it operational.

\section{Medical schools still not declaring financial conflicts}

Many US medical schools do not have policies to address potential conflicts of interest, according to a study published last week (S. H. Ehringhaus et al. J. Am. Med. Assoc. 299, 665-671; 2008).

In a survey by Susan Ehringhaus, associate general counsel at the Association of American Medical Colleges, and her colleagues, just $38 \%$ of the 86 medical schools that responded reported having a policy in place that covers their financial interests, such as royalties and stocks. Another 37\% of schools said that they were working on developing a policy.

The numbers rose markedly when the schools were asked whether they had policies to cover individuals: $71 \%$ of the schools had policies for senior officials and $66 \%$ had them in place for governing board members. 